\title{
Elk management strategies and profitability of beef cattle ranches
}

\author{
WENDY L. F. TORSTENSON, MICHAEL W. TESS, AND JAMES E. KNIGHT
}

Authors are Research Associate, Professor, and Wildlife Extension Specialist, Department of Animal and Range Sciences, Montana State University, Bozeman, Mont. 59717-2900.

\begin{abstract}
Computer simulation was used to determine the effects of wild elk (Cervus elaphus) on available forage, cattle herd size, and ranch gross margin in southwestern Montana beef cow-calf production systems. Data collected from 5 southwestern Montana ranches were used to develop input parameters for bio-economic models of elk forage harvest and beef production. Input parameters described ranch resources, animal inventories, and animal management. Cattle herd size ranged from 241 to 1147 head. Elk numbers varied by season within ranch and ranged from 49 to 421 head. Ranches were simulated as currently managed with elk present and with $10,20,30$, and $100 \%$ of the elk removed. Simulated management scenarios were replicated 10 times. Data from each ranch were analyzed by one-way analysis of variance. Cattle herd size, gross margin, and available forage significantly $(P<0.05)$ increased when all elk were removed; however, the magnitude of these effects differed among ranches. Removal of all elk permitted cattle herd size to increase from 7 to $32 \%$ across ranches. Annual costs of elk on the 5 ranches (i.e., increase in gross margin from elk removal) ranged from $\$ 5,949$ to $\$ 21,152$. On an AUM basis, elk costs ranged from $\$ 8.55$ to $\$ 14.51$. Three management alternatives were evaluated for their potential to recover elk costs: Montana's Block Management Program, coordinated exchange of forage use, and leasing of hunting access. For each ranch, at least one of these management strategies could recover all estimated costs of providing elk habitat. Elk can significantly reduce profits for cow-calf ranches in southwestern Montana. Elk impacts on beef enterprise profits are closely associated with efficiency of resource use by cattle-i.e., ranches with lower unit costs of production lose more gross margin by providing forage for elk compared to ranches with higher production costs.
\end{abstract}

Key Words: range economics

Beef cattle and elk (Cervus elaphus) are important parts of the economy and heritage of the Rocky Mountain West. As native wild ungulates, elk are important components of healthy ecosystems. Elk and cattle use similar habitats and prefer similar diets for much of the year. Because private lands, primarily livestock ranches, provide an important part of annual elk habitat, cattle-elk interactions are important to public resource managers and live-

Research was funded in part by USDA-NRICGP

Journal Series No. 2001-39, Montana Agricultural Experiment Station.

Manuscript accepted 20 Jul. 01.
Resumen

Simulación por computadora fue usada para determinar los efectos del alce silvestre (Cervus elaphus) en forraje disponible, tamaño del hato de ganado, y margen bruto del rancho en sistemas de producción vaca- becerro en el suroeste de Montana. Los datos recolectados de 5 ranchos del suroeste de Montana fueron usados para desarrollar parámetros de entrada para modelos bio-económicos del consumo de forraje del alce y la producción de ganado de carne. Los parámetros de entrada describieron los recursos del rancho, inventario y manejo de animales. El tamaño del hato de ganado varió de 241 a 1147 cabezas. El número de alces varió por temporada en el rancho y fluctuó entre 49 a 421 cabezas. Los ranchos fueron simulados tanto como si el alce estuviera presente como si este hubiera sido retirado de los mismos. Escenarios de administración simulados fueron repetidos 10 veces. Los datos fueron analizados por procedimientos de mínimos cuadrados, contabilizando los efectos del alce. El tamaño del hato de ganado, el margen bruto, y el forraje disponible incrementó significativamente $(P<0.05)$ cuando los alces fueron retirados; aunque la magnitud de estos efectos fue diferente entre ranchos. El retirar todos los alces permitió que el tamaño del hato de ganado se incrementara de 7 a $32 \%$ entre los diferentes ranchos. Los costos anuales del alce en los 5 ranchos (e.g., incremento en el margen bruto por el retiro del alce) variaron de US\$ 5, 949 a US\$ 21,152. Sobre la base de unidades animal por mes (UAM), los costos del alce variaron de US\$ 8.55 a US\$ 14.51. Tres alternativas de manejo fueron evaluadas por su potencial para recuperar los costos del alce: programa de administración por bloque de Montana, intercambio coordinado de uso de forraje, $y$ renta por acceso a la caza del alce. Para cada rancho, al menos una de estas estrategias podría recuperar todos los costos estimados de proveer un hábitat para el alce. El alce puede reducir significativamente las ganancias de ranchos vacabecerro en el suroeste de Montana. Los efectos del alce en empresas de ganado de carne están asociados con la eficiencia del uso de los recursos por el ganado (e.g., ranchos con bajos costos unitarios de producción pierden mas margen bruto al proveer forraje para el alce, comparados con ranchos con altos costos de producción).

stock producers (Adams 1982, Skovlin 1982, Alt et al. 1992, Henderson and O'Herrin 1992).

Interactions between cattle and elk sharing habitats are complex and determined by many factors (Smith 1961, Vavra et al. 1989). These factors include similarity of feeding strategies, and spatial, temporal and dietary overlap (Mackie 1970; Edge and Marcum 1990, Vavra 1992, Sheehy and Vavra 1996). For competi- 
tion for forage to occur, both cattle and elk must be consuming the same forage species in the same area and the forage species must be in short supply (Murie 1951, Gordan 1968, Wagner 1969, Holechek 1980, Vavra et al 1989, Vavra 1992, Edge and Marcum 1990).

Given the goals of environmental and economic sustainability, when elk and cattle share the same habitats, numbers of both species may need to be reduced in order to prevent damage to the range resource. Assuming cattle prices are above breakeven prices and other sources of income are held constant, a reduction in cattle numbers will reduce ranch profit. For beef producers on private land, most strategies to preserve ranch income involve minimizing competition between elk and cattle and (or) deriving supplemental income from elk. The relative economic benefits of these alternatives have not been studied.

The objectives of our research were to: 1) evaluate the effects of elk populations on profitability of beef cattle enterprises, and 2) compare alternative elk/cattle management strategies for their effects on ranch profitability.

\section{Materials and Methods}

Five ranches located in southwestern Montana cooperated in the study. Livestock, wildlife, and management data collected from each ranch were used to develop input parameters for 2 computer simulation models. The first model predicted forage harvest by elk based on number, age, sex, reproduction and season of use. The second model simulated cattle performance and profit for the ranch.

\section{Ranch and Cattle Data}

Five ranches were selected as representatives of southwestern Montana. Criteria for selection were that the ranch was a beef cow-calf operation with: a) private land representing a large portion of the resource base, $b$ ) revenues from the sale of cattle constituting its primary source of income, and c) migratory and (or) resident elk using the ranch for at least part of the year. Advice on suitable ranches was received from Montana Fish, Wildlife \& Parks (FWP) biologists and Montana State University Extension personnel.

Inventories and descriptions of forage resources and cattle grazing strategies were obtained from each ranch. Cattle data included: herd size, genetic composition, replacement strategies, breeding seasons, health management, nutritional management, marketing practices, and performance measures for reproductive rate, mortality, and growth. Feeding management data included amounts and type of forage, dates when cattle were moved on and off range, along with how each management group was treated (Table 1).

\section{Elk data collection}

Estimates of the number of elk on each ranch were obtained from FWP biologists and ranch managers. Yearly flight data (FWP) for elk numbers were used to categorize elk herds into bulls, cows, and calves. Most flights occurred after the hunting season and near the end of winter after a large portion of elk mortality had occurred. Calves were assumed to be $50 \%$ male. Taber et al. (1982) constructed static life tables (defined by Begon et al. 1990) based on field studies of Rocky Mountain elk. We adapted their reproductive percentages to determine age distributions within sex. Amount of time and type of activity elk spent on the ranches was determined from interviews with FWP biologists and ranch managers.

Dietary overlap (percentage of elk diet, by season, that would be potentially consumed by cattle if available) was determined from literature reports based on vegetation types that we judged to be relevant to the habitats found on the 5 ranches (Murie 1951, Stevens 1966, Gordon 1968, Mackie 1970, Nelson 1982, Peek 1982, Kasworm et al. 1984). Similarly, spatial overlap (percentage of habitat used by elk, by season, that was used by cattle sometime during the year) was estimated based on literature reports (Smith 1961, Mackie 1970, Skovlin 1982, Witmer and deCalesta 1983, Hart et al. 1991, Yeo et al. 1993) and by interviews with ranch managers and local FWP biologists.

Table 1. Characteristics of ranches simulated. ${ }^{a}$

\begin{tabular}{lrrrrr}
\hline \hline Ranch & 1 & 2 & 3 & 4 & 5 \\
\hline Herd Size & 240 & 368 & 838 & 900 & 1142 \\
Weaning Weight, kg & 262 & 251 & 257 & 265 & 235 \\
Cow Mature Weight, kg & 595 & 550 & 544 & 544 & 550 \\
Conception Rate, \% & 92 & 93 & 92 & 92 & 95 \\
Breeding Date & May & May 22 & May 20 & May 10 & June 1 \\
Breeding Season, days & 75 & 60 & 90 & 50 & 90 \\
Death Loss, \% & 2.5 & 3.0 & 3.0 & 5.0 & 10.0 \\
Native Range, days & 132 & 138 & 214 & 85 & 201 \\
Domestic Pasture, days & 38 & 46 & 30 & 136 & 29 \\
Winter Feeding, days & 195 & 181 & 121 & 144 & 135 \\
Wean \& Sale Date & Oct 20 & Oct 20 & Nov 8 & Oct 25 & Nov 1 \\
\hline
\end{tabular}

${ }^{\mathrm{a}}$ Herd Size $=$ number of beef cows exposed to bulls per year, including replacements; Weaning weight $=$ average weaning weight of steers and heifers; Breeding Date = first day of breeding for mature cows, all ranches except \#2 bred yearling heifers earlier (Ranch $1=14 \mathrm{~d}$, Ranches $3 \& 5=10 \mathrm{~d}$, Ranch $4=30 \mathrm{~d}$ ); Breeding Season = length of season for mature cows; Death Loss $=$ calves lost from birth to weaning; Domestic Pasture $=$ early spring pasture $($ Ranch 4$)$ and hay aftermath (all ranches).

\section{Elk Forage Consumption Model}

In an effort to quantify dietary overlap between elk and cattle, many researchers have compared forage intake by elk to the standard AUM. Intuitive reasoning has formed the basis for many estimates of AUM equivalents (Holechek 1980). Several estimates have been based simply on body weight (Murie 1951, Stoddart and Smith 1955, Loomis et al. 1989, Lacey et al. 1993). Calculations based on weight alone risk errors due to differences in gender, animal physiological state, and spatial and dietary overlap (Holechek 1980, Nelson and Leege 1982).

An AUM is a useful, but imprecise method of measuring forage intake (SRM 1989). A more precise measure of what an animal eats would be based on caloric intake. Because energy is usually the limiting nutrient under range conditions, animals eat to meet its energy requirements (Vavra 1992), and intake is expected to vary with gender and physiological state. Because the energy density of forages changes with plant maturity, dry matter intake will change with plant maturity for animals in the same physiological state.

The purpose of our elk model is to simulate forage consumption by wild elk in an effort to quantify dietary overlap between elk and domestic cattle. The model takes into account the different physiological needs of elk as related to age, sex, reproductive status, and time of year, as well as forage quality and dietary and spatial overlap of elk and cattle. The model is deterministic and relatively simple. We emphasize that the primary purpose of the model is to estimate forage removal by an existing elk herd, and not to simulate the dynamics of a herd in response to changing resources. See Appendix for further description of the model and the equations used. 


\section{Beef Cow-Calf Model}

The beef cow-calf model developed by Tess and Kolstad (2000a,2000b) was used to simulate cattle and ranch enterprise performance. The model simulates performance of beef cattle of varying genetic types in response to changes in forage quality and management strategies, and simulates economic performance of beef production systems in response to alternate breeding and management systems. It uses parameters input by the user describing genotypes, mating systems, nutritional characteristics of native range and stored feed, management decisions, input costs, and cattle prices. Importantly, the model simulates performance of ranches of fixed size-i.e., the grazed forage base is a fixed number of AUM. Resource and management data for the ranches used in the simulations are presented in Table 1. Input prices and cattle prices used were averages during 1996.

The beef simulation model produces several measures of system performance. Only 3 statistics will be reported here. Because the model simulates a ranch with a fixed range resource base, adding resources or changing the management of the range forage base can lead to differences in annual cattle herd carrying capacity. Hence, herd size (specifically, the number of cows exposed for breeding) provides a measure of carrying capacity. Ranch gross margin, computed as gross income minus variable costs, provides a measure of profitability for each ranch when the ranch is constrained to a fixed range resource base. This economic measure considers some expenses as fixed for example, home raised hay, grazed forage, property taxes, and some family labor. In contrast, unit cost of production (specifically, input cost per $\mathrm{kg}$ of steer equivalent weight sold) provides a measure of production efficiency treating all input costs as variable and without constraints. In other words, for this measure of economic efficiency, all resources used, including raised hay and grazed forage, are priced at their rental values and are not considered to be in limited supply. See Tess and Kolstad (2000a,2000b) for further details.

\section{Integration of Elk and Cattle Data}

The elk forage model was used to determine forage harvest by elk on each ranch. Forage use by elk was equated to AUM that potentially could have been used by cattle if elk were not present and if elk were eating what the cows could accessi.e., as affected by slope, terrain, etc. It is important to understand that our definition of a fixed forage resource base assumes that there is a fixed amount of forage produced annually that can be grazed without harming the range resource.

Using the cow-calf model, ranches were simulated as they were actually managed. To compare how these ranches could theoretically be run if elk were not present, AUM harvested by elk on the respective ranches, as determined by the elk forage model, were added into the cow-calf model for the individual ranches. Comparisons of these simulations, allowed us to determine how many additional cattle could be maintained on the ranches due to an increase in forage if elk were not present, and the effects this had on ranch gross margin. Amounts of home-raised hay and domestic pasture were also considered fixed for each ranch. Hence, adding range resources would allow each ranch to run more cattle, but also might require the purchase of additional hay for winter feeding.

\section{Alternative Management Strategies}

Several potential methods exist by which beef cattle ranchers can reduce conflict between elk and cattle and (or) recover costs associated with elk on private lands. Variability of available resources on ranches and the number of elk utilizing the ranches makes it difficult to find a single best solution to the problem.

Block Management. In Montana, the Block Management Program was devised to keep private lands open for public hunting, while paying landowners for allowing free hunter access. Through management of the number and strategic placement of hunters, more efficient hunting is expected, thereby reducing elk herd numbers (Governor's Advisory Council on Private lands/Public Wildlife, unpublished). In addition to assisting landowners with hunter management, the program also offers benefits that reduce or eliminate the cost of having hunters on private land, and in some cases offers taxable reimbursements of up to $\$ 8,000$ (Montana Session Laws 1995).

To mimic more efficient hunting, each ranch was simulated with elk herds reduced by 10,20 , and $30 \%$. Effects on cattle herd size and gross margins were evaluated.

Coordinated Exchange of Forage Use. Coordinated grazing of rangelands among state, federal, and private lands allows private landowners to rest pastures that have been grazed by elk during the fall, winter, and (or) spring (Frisina and Morin 1991, Alt et al. 1992). With the exchange of for- age, landowners may not have to purchase stored forage to replace forage removed by elk. For example, members of the Wall Creek Stock Association participating in the Wall Creek Wildlife Management Area exchange of use program received an additional month of livestock grazing, resulting in an extra 826 AUM of grazing by cattle (Alt et al. 1992). A major limitation of this scenario is that there must be available state and federal lands close enough to the private landowner to make transporting cattle to these public ranges feasible. To evaluate this scenario, the fair market value of an AUM on private property was compared to the value of an AUM as simulated for each of the five ranches.

Leasing Hunting Access. Leasing private land to outfitters in Montana is a common, but sometimes controversial, practice. Hunters are willing to pay for the opportunity to hunt elk, particularly if they are assured of an un-crowded hunt. This "market" allows outfitters to lease land from ranchers at a value that increases the landowners' income.

There are several forms of fee hunting. However, for this study, we chose only the leasing of the land to an outfitter. Once land was leased to an outfitter it was assumed that no further costs associated with hunters, such as time spent managing or guiding hunters, would be incurred by the rancher. Also, the monetary value of the lease was fixed, whereas if a landowner were to lease hunting access to individual hunters, the income would be variable, dependent on the number of hunters wanting to hunt.

To determine the value of a lease on each ranch, a survey was sent to 100 outfitters in FWP hunting regions 1, 2, and 3, where elk hunting is prevalent. Survey procedures were based on previous studies (Swensson and Knight 1998, 2001). The survey consisted of a cover letter explaining the study and what was being asked of the outfitter; general maps of the individual study ranches showing county roads and habitat types; and a description of the elk herd that occupied the ranch during hunting season. The elk herd was described by percentage of bulls in various age classes, as well as number of calves per 100 cows and number of bulls per 100 cows. Outfitters were requested to estimate the market value of each lease. Six weeks after mailing the initial surveys, follow-up phone calls were made to a random $50 \%$ of the non-respondents. Reasons for not completing the survey were determined. When feasible, non-respondents were again asked to complete the survey. 


\section{Statistical Analyses}

Five scenarios were simulated in determining the effects of elk on ranches. To meet our first objective, each ranch was simulated as currently managed with elk present. The simulations were repeated with elk removed from the ranch, i.e., forage resources utilized by elk were added to the AUM available for cattle. These simulations also provided insights into the merits of the exchange of forage management strategy. To evaluate the potential effects of partial reduction in the elk herds, as might be expected due to Block Management, each ranch was simulated with a 10,20 , or $30 \%$ reduction in the ranch's elk population.

Due to the stochastic nature of the beef cow-calf model (reproductive traits exhibit random variation; Tess and Kolstad 2000a), it is possible to statistically compare simulated systems. Because not all traits are modeled with random variation, simulated variation between replicates is not the same as would be measured among actual ranches; however, the variation simulated does provide a basis for evaluating differences. Hence, each ranch/scenario combination was replicated ten times.

Because variances differed among ranches, simulated data for each ranch was analyzed separately. One-way analysis of variance was conducted to evaluate treatment effects (i.e., $0,10,20,30$, or $100 \%$ elk removal) on ranch gross margin and cattle herd size (SAS 1992). Means were separated using Duncan's Multiple Range test.

Results of the outfitter surveys were summarized by computing simple means and standard deviations of the estimated lease values.

\section{Results}

\section{Elk AUM Equivalents}

Table 2 illustrates the performance of the elk model for animals of different sexes and physiological states, and consuming forage of different quality. To a large degree, previous estimates of AUM equivalents have been based on differences in mature weight between elk and cattle, assuming that intake of elk was proportional to cattle but not considering physiological state. Murie (1951) and Loomis et al. (1989) used values of 0.25 and 0.27 for elk calves. Coupled with their value for lactating elk cows (0.67), the values of Loomis et al. (1989) agree with the model's predictions. Arychuk (2000) distinguished yearlings (0.3), adult females (0.5) and adult males (0.7).

Table 2. Effects of variable forage energy content and physiological state of elk on animal unit value equivalents. ${ }^{\text {a }}$

\begin{tabular}{lcccccccc}
\hline \hline & \multicolumn{2}{c}{ Male } & \multicolumn{2}{c}{ Female-N } & \multicolumn{2}{c}{ Female-G } & \multicolumn{2}{c}{ Female-L } \\
\hline & & & \multicolumn{4}{c}{ Metabolizable energy per kilogram dry matter } \\
Age & 2.00 & 1.70 & 2.00 & 1.70 & 2.00 & 1.70 & 2.00 & 2.13 \\
Y1 & 0.47 & 0.56 & 0.43 & 0.49 & N/A & N/A & N/A & N/A \\
Y2 & 0.59 & 0.67 & 0.50 & 0.57 & 0.49 & 0.59 & 1.01 & 0.89 \\
M & 0.63 & 0.79 & 0.51 & 0.63 & 0.53 & 0.65 & 0.96 & 0.87 \\
\hline
\end{tabular}

${ }^{\mathrm{a}} \mathrm{Y} 1$ = yearling, $\mathrm{Y} 2$ =two-year old animal, and $\mathrm{M}=$ mature animal of five-years old or older. Female- $\mathrm{N}=$ non-reproductive female, Female-G = gestating female, and Female- $\mathrm{L}=$ lactating female, including calf.

Previous AUM equivalents for adult elk (sex not specified) include 0.4 (Murie 1951, Meresczak et al.1981, Loomis et al. 1989, Wisdom 1992), 0.5 (Stoddart and Smith 1955, Skovlin et al. 1968, Lacey et al. 1993), 0.6 (Lacey et al. 1988), 0.65 (Vallentine 1990), and 0.75 (Telfer and Scotter 1975).

Our results demonstrate the effects that age, gender, physiological state, and forage quality can have on forage intake. By accounting for these variables and dietary overlap, our model permits more precise description of the study case. These results also point to the hazards of using single, general predictions of AUM consumed by elk, because such predictions cannot account for species differences in food habits and distribution across rangelands (Vavra 1992).

\section{Animal Use and Ranch Resources}

Numbers of elk utilizing the ranches were likely conservative (Table 3 ). With only one yearly flight to determine the population characteristics of a herd for the

Table 3. Summary of elk herds on individual ranches. ${ }^{a}$

\begin{tabular}{lcccc}
\hline \hline Ranch & Age Class & Male & Female-N & Female-R \\
\hline 1 & Y0 & 9 & 9 & 2 \\
& Y1 & 8 & 13 & 6 \\
& Y2 & 2 & 7 & 25 \\
2 & M & 9 & 28 & \\
& Y0 & 32 & 32 & 22 \\
& Y1 & 30 & 45 & 91 \\
& Y2 & 5 & 25 & \\
3 & M & 29 & 102 & 6 \\
& Y0 & 24 & 24 & 15 \\
& Y1 & 21 & 31 & 62 \\
4 & Y2 & 7 & 18 & 3 \\
& M & 19 & 71 & 9 \\
& Y0 & 26 & 26 & 35 \\
5 & Y1 & 4 & 17 & 4 \\
& Y2 & 3 & 9 & 12 \\
& M & 5 & 41 & 49 \\
\hline
\end{tabular}

${ }^{a}$ Numbers shown are estimated maximum populations.

$\mathrm{Y} 0=$ calves, $\mathrm{Y} 1=$ yearlings; $\mathrm{Y} 2=2$ year olds; $\mathrm{M}=3$ +years

Female- $\mathrm{N}=$ non-reproductive female; Female- $\mathrm{R}=$ reproductive female. entire year, we assumed no recruitment of bachelor bulls took place, and average recruitment through reproduction occurred.

Elk use and numbers varied across ranches. All ranches showed an influx of elk in late fall that continued to early spring (Table 4). In general, there was a decline in elk numbers during the summer as elk migrated to higher elevation habitats, typically on state and federal lands. The exception to this was Ranch 5, which provided calving grounds to 250 cow elk. Four of the 5 ranches supported both resident and migratory populations of elk.

Elk-use data presented in Table 4 represent our best estimates for the product of spatial and dietary overlap between elk and cattle by season and reflect differences due to forage species, elevation, slope, ruggedness, and distance from water (also see review by Fuller 1997). Late fall and winter showed the highest percentages of resource overlap of up to $90 \%$, with the exception of Ranch 2 . The manager of Ranch 2 felt there was only $20 \%$ overlap due to the fact that all hay 
Table 4. Summary of elk use on individual ranches.

\begin{tabular}{llccr}
\hline \hline Ranch & Period of Use & Number of Elk & Overlap $^{\text {a }}$ & AUM \\
\hline 1 & Oct 1 - Nov 30 & 118 & 90 & 110 \\
& Dec 1 - May 15 & 118 & 75 & 262 \\
& May 16 - May 31 & 118 & 75 & 22 \\
2 & June 1 - Oct 1 & 71 & 40 & 68 \\
& Oct 1 - Nov 30 & 199 & 90 & 186 \\
& Dec 1 - Mar 31 & 347 & 20 & 156 \\
& Apr 1 - May 30 & 421 & 40 & 182 \\
& June 1 Sept 9 & 331 & 50 & 328 \\
3 & Sept 10 - 30 & 199 & 80 & 70 \\
& Oct 1 - Nov 30 & 290 & 90 & 271 \\
& Dec 1 - Apr 15 & 298 & 85 & 673 \\
& Apr 16 - Jun 20 & 249 & 40 & 111 \\
& Jun 21 - Sept 9 & 199 & 50 & 169 \\
4 & Sept 10 - 30 & 290 & 80 & 157 \\
& Oct 1 - Nov 30 & 178 & 90 & 333 \\
& Dec 1 - Mar 31 & 178 & 90 & 27 \\
& Apr 1 - Jun 20 & 49 & 40 & 63 \\
& Jun 2 - Sept 9 & 100 & 50 & 173 \\
& Sept 10 - 30 & 178 & 80 & 245 \\
& Oct 1 - Nov 30 & 194 & 90 & 168 \\
& Dec 1 - Apr 15 & 114 & 85 & 66 \\
\hline May 15 - Aug 15 & 250 & 40 &
\end{tabular}

${ }^{\mathrm{a} O v e r l a p}=$ dietary and spatial overlap between elk and cattle, $\%$.

Table 5. Simulated ranch performance without elk removal. ${ }^{\mathrm{a}}$

\begin{tabular}{lccccc}
\hline \hline Ranch & Herd Size & Cattle AUM & & $\begin{array}{l}\text { Elk w/o } \\
\text { Overlap }\end{array}$ & Cattle used by Elk \\
\hline & & & $(\$ / \mathrm{kg})$ & $-\cdots($ AUM $)---$ \\
1 & 241 & 1,835 & 1.62 & 674 & 462 \\
2 & 368 & 2,820 & 1.65 & 2,189 & 922 \\
3 & 838 & 7,750 & 1.53 & 1,836 & 1,325 \\
4 & 902 & 7,760 & 1.58 & 857 & 661 \\
5 & 1,147 & 9,200 & 1.80 & 987 & 654 \\
\hline
\end{tabular}

${ }^{\mathrm{a}}$ Herd Size $=$ number of beef cows exposed per year, including replacements. Cattle AUM = AUM used by cattle; $\$ \mathrm{~kg}=$ unit cost of beef production; Elk AUM w/o overlap = AUM used by elk without considering dietary and spatial overlap Cattle AUM used by Elk = AUM that could be used by cattle if elk were not present.

Table 6. Simulated effects of elk herd reduction on beef enterprise performance.

\begin{tabular}{|c|c|c|c|c|c|c|}
\hline \multirow[b]{2}{*}{ Ranch } & \multicolumn{5}{|c|}{ Percentage Reduction in Elk Numbers } & \multirow[b]{2}{*}{ SEM } \\
\hline & 0 & 10 & 20 & 30 & 100 & \\
\hline \multicolumn{7}{|c|}{ Cattle Herd Size $=$ Cows Exposed/Year } \\
\hline 1 & $241^{\mathrm{e}}$ & $247^{\mathrm{d}}$ & $253^{\mathrm{c}}$ & $260^{\mathrm{b}}$ & $301^{\mathrm{a}}$ & 0.74 \\
\hline 2 & $368^{\mathrm{e}}$ & $381^{\text {d }}$ & $394^{\mathrm{c}}$ & $404^{b}$ & $486^{\mathrm{a}}$ & 1.10 \\
\hline 3 & $838^{\mathrm{e}}$ & $851^{\text {d }}$ & $867^{\mathrm{c}}$ & $881^{\mathrm{b}}$ & $979^{\mathrm{a}}$ & 1.54 \\
\hline 4 & $902^{\mathrm{e}}$ & $905^{\mathrm{d}}$ & $917^{\mathrm{c}}$ & $924^{b}$ & $978^{\mathrm{a}}$ & 1.08 \\
\hline 5 & $1,147^{\mathrm{d}}$ & $1,148^{\mathrm{d}}$ & $1,155^{\mathrm{c}}$ & $1,166^{\mathrm{b}}$ & $1,228^{\mathrm{a}}$ & 2.46 \\
\hline \multicolumn{7}{|c|}{ Ranch Gross Margin, \$/year } \\
\hline 1 & $64,879^{c}$ & $66,185^{\mathrm{c}}$ & $65,925^{\mathrm{c}}$ & $67,981^{b}$ & $71,193^{\mathrm{a}}$ & 586 \\
\hline 2 & $88,682^{\mathrm{b}}$ & $89,126^{\mathrm{b}}$ & $89,961^{\mathrm{b}}$ & $90,996^{\mathrm{b}}$ & $100,487^{\mathrm{a}}$ & 827 \\
\hline 3 & $176,715^{\mathrm{c}}$ & $181,066^{\mathrm{b}}$ & $181,010^{b}$ & $183,084^{\mathrm{b}}$ & $197,867^{\mathrm{a}}$ & 1,099 \\
\hline 4 & $232,861^{\mathrm{c}}$ & $234,829^{c}$ & $234,227^{\mathrm{c}}$ & $237,534^{\mathrm{b}}$ & $242,151^{\mathrm{a}}$ & 919 \\
\hline 5 & $237,756^{\mathrm{b}}$ & $241,457^{\mathrm{ab}}$ & $243,019^{\mathrm{a}}$ & $243,536^{\mathrm{a}}$ & $243,705^{\mathrm{a}}$ & 1637 \\
\hline
\end{tabular}

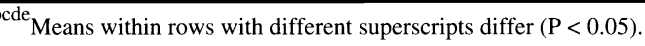

was stored in "elk-proof" sheds, and elk did not generally intermingle with cattle during winter feeding of hay. In general, summer months showed only a $40 \%$ overlap mostly due to changes in dietary preferences of elk from grasses to forbs (Murie 1951, Mackie 1970).

Table 5 summarizes ranch performance under actual management and elk numbers. Differences in production costs $(\$ / \mathrm{kg})$ were due to several factors. Reproductive rates were similar among ranches; however, calf mortality was high for Ranch 5, spreading production costs over less output. Due to snow cover, Ranches 1 and 2 fed hay for extended periods, increasing feed costs.

By accounting for less than complete dietary and spatial overlap (Table 4), AUM harvested by elk in competition with cattle were considerably less than might be predicted otherwise (Vavra et al. 1989, Kingery et al. 1996). This highlights the importance of dietary overlap in quantifying potential competition between livestock and wildlife.

\section{Forage Resources Gained From Elk Removal}

Differences among ranches in gross margin reflect differences in herd size as well as differences in unit costs of production (Table 6). Recovering all forage resources used by elk (i.e., 100\% elk removal) increased cattle carrying capacity and gross margin for each ranch $(\mathrm{P}<$ 0.05 ); however, responses were unique for each ranch. The ratio of added AUM to added cows ranged from 7.7 to 9.4 , indicating how ranches differed in their dependence on range resources. Because of their short grazing seasons, Ranches 1 and 2 added more cows per AUM than Ranch 3, which was able to graze for nearly two months longer. Ranches 4 and 5 were intermediate.

The value of added AUM (added gross margin divided by added AUM) also differed among ranches; however, standard errors were large. Because this statistic was deemed important to the interpretation of results, we repeated the simulations for the base scenario, and the scenario assuming total removal of elk. This time we replicated each scenario 200 times. Estimated values of an added AUM ranged from $\$ 8.55$ to $\$ 14.51$ (Table 7). Differences were related to, but not totally explained by differences in grazing season. Ranches that grazed longer and fed less hay were generally more efficient (i.e., lower production costs, $\$ / \mathrm{kg}$ ) and recovered more gross margin per added 
Table 7. Simulated added AUM value after removal of all elk.

\begin{tabular}{lc}
\hline \hline Ranch & Added AUM Value $^{\mathrm{a}}$ \\
\hline 1 & $\$ 11.95$ \\
2 & $\$ 11.87$ \\
3 & $\$ 14.51$ \\
4 & $\$ 13.73$ \\
5 & $\$ 8.55$ \\
\hline
\end{tabular}

$\overline{{ }^{a} \text { Added AUM value }=\text { Added ranch gross margin divided }}$ by added AUM, based on 200 replicates.

AUM. The exception was Ranch 5, where unit cost of production was high primarily due to high calf mortality. In a survey conducted by Lacey et al. (1993) landowners in southwestern Montana reported average annual losses to big game of 511 AUM ( 214 due to elk) and 7.5 metric tons of hay, valued at \$6,066-i.e., \$11.87/AUM.

\section{Block Management}

Incentives for ranchers to participate in the Montana Block Management Program include hunter management, monetary compensation, and potentially some reduction in elk numbers. According to Montana Session Laws (1995) ranches participating in the Block Management Program are entitled to some benefits, including a monetary benefit of up to $\$ 8,000$, depending on the type of habitat provided for wildlife, species and number of wildlife present, and access provided to adjacent private and public lands. We simulated 10, 20, and $30 \%$ reductions in elk numbers to evaluate economic effects on each ranch.

Responses to reduction in elk numbers (Table 6) were essentially linear because we assumed no change in elk sex or age structure, only population size. However, slopes of the responses were not the same across ranches, which reflect differences among ranches in elk population structure, as well as differences in dietary overlap. Ranches 1, 2, 3, and 4 were able to increase cattle numbers $(\mathrm{P}<0.05)$ by reducing elk by $10 \%$, and all ranches experienced significant increases in cattle numbers when elk were reduced by $20 \%$. Only Ranch 3 increased gross margin $(\mathrm{P}<0.05)$ with a $10 \%$ reduction in elk numbers. Ranch 2 was unable to increase gross margin with even a $30 \%$ reduction in elk numbers.

These results suggest that elk herd reduction is likely to be of only minor benefit to ranches participating in Block Management. However, expenses associated with elk were less than $\$ 8,000$ on Ranches 1 and 5, suggesting these ranches could potentially recover all elk costs through participation in the Block Management Program, even without a reduction in elk numbers.

\section{Outfitter Lease}

Sixteen of the 100 mail surveys were returned. Five surveys were removed from the data because they were not completed properly. Follow-up phone calls made to a random half of non-respondents indicated that many of the outfitters felt unqualified to value a lease on private land because their business was limited to public land. Follow-up calls increased the number of useable surveys back to 16 .

Based on their comments, outfitters gave conservative estimates for the value of a 1-year lease on the individual ranches for elk hunting (Table 8). Some respondents noted that leases would be worth more if deer hunting were included and if leases were of longer duration than just 1 year. All respondents agreed that it was very difficult to gauge an accurate price quote for a ranch without actually having been on the ranch during a hunting season to see the behavioral patterns and population characteristics of the elk herd. Also, aesthetics, reputation, and rapport between client and outfitter are difficult to measureyet can have a large influence on the price an outfitter is able to get for a hunt (Knight et al. 1995), which in turn influences the value of the lease.

Mean values assigned by the outfitters were all below the simulated costs of providing elk habitat on private land; yet there was a wide range of estimates for each lease. Each ranch was valued by at least one outfitter above elk costs. Though not accounted for in the simulations, Ranches 3, 4, and 5 did receive some annual income from elk hunting. For example, Ranch 3 leased hunting access for $\$ 25,000 / y r$, which is less than the maximum value assigned by the outfitter surveys but more than our estimated expenses associated with elk.

\section{Exchange of Forage Use}

In theory, exchange of forage use with a state or federal resource management agency should fairly recover all expenses associated with elk, except possibly repair costs for fences and other improvements (note, that in Montana FWP provides some ranchers with panels to protect haystacks from wildlife). This assumes that added AUM allotted to ranches on

Table 8. Lease value of ranches for elk hunting based on outfitter survey.

\begin{tabular}{lcrrrr}
\hline \hline Ranch & 1 & 2 & 3 & 4 & 5 \\
\hline Mean & $\$ 2,919$ & $\$ 3,900$ & $\$ 10,375$ & $\$ 7,175$ & $\$ 2,953$ \\
Maximum & $\$ 6,700$ & $\$ 15,000$ & $\$ 30,000$ & $\$ 17,700$ & $\$ 7,500$ \\
Standard deviation & $\$ 2,288$ & $\$ 3,850$ & $\$ 7,386$ & $\$ 5,129$ & $\$ 2,520$ \\
\hline
\end{tabular}

public land are equal to or greater than the AUM consumed by elk on private land. Table 5 shows our estimates of the number of AUM needed for an equitable exchange of use.

The fair market value of an AUM lease is the price a person would expect to pay if he/she leased land for the purpose of grazing cattle. Average rates for a "cow-calf pair" in Montana were $\$ 13.90$ and \$15.60, in 1996 and 2000, respectively (NASS 2001). Reported lease rates do not account for differences in cattle mature size; hence, they are not easily compared to AUM values reported here. On average, $30 \%$ of a private grazing lease represents landlord services such as fence maintenance, water access, etc. (Torell and Fowler 1992, LaFrance and Watts 1995), which were not varied in our simulations. Following such adjustment, average Montana lease rates would be $\$ 9.73$ and $\$ 10.92$ for 1996 and 2000, respectively. Our estimates of the value of an AUM recovered from elk use for the 5 ranches are above and below these values (Table 7). Interestingly, these results suggest that it may be more advantageous for some ranchers to accept fair market value of AUM eaten by elk rather than accept a direct exchange of forage use. On the other hand, ranches that show returns per AUM higher than lease values may be better off exchanging use with a public agency, if available.

The main focus of exchange of use in this study was on the monetary value of such an alternative management scheme. Where feasible, a coordinated exchange of use has other beneficial elements than just recouping costs associated with elk. As noted by Alt et al. (1992) and Frisina and Morin (1991), a cooperative grazing system actually increased available AUM by improving forage on the range. This had a secondary effect of keeping elk on wildlife management areas for a longer period of time before elk migrated to private ranges in search of food. Potential benefits of grazing on subsequent forage nutritional quality may be due to removal of old growth and delayed senescence, though studies have shown mixed results (Anderson and Scherzinger 1975, Severson and Urness 1994, Hobbs et al. 1996a, Wambolt et al. 1997). Increased 
landowner tolerance of elk, while increasing cattle and elk numbers able to use the land (Frisina and Morin 1991) are other advantages to exchanging use of forage.

\section{Discussion}

Simulation is a tool to examine scenarios that are beyond the scope of experimentation. It is used to address questions that are too expensive or too time consuming to address with experimentation. Often these questions take the form of: "How would the system respond if ? ? The assumptions made and the boundaries of the models used define what inferences can be made from the studies. Our work represents an attempt to integrate a large amount of published research into a systems framework, and make a science-based application to a real-life issue; in this case estimating costs of providing wildlife habitat on private land, and evaluating methods to recoup these costs.

The accuracy of our predicted costs could be improved by more precise measures of elk population parameters, including diet composition. However, it should be noted that the type of data available to us in this study is the type of data available to resource managers, policy makers, and ranchers. Ranch managers know the number and classes of livestock. On the other hand, data on wild ungulates are "generally obtained from state wildlife agencies or collected in cooperation with such agencies" (Cooperrider and Bailey 1984). To account for imprecision in elk population parameters, using results presented in Tables 5 and 6 one could decrease or increase the number of elk to bracket a range of costs. Similar tactics could be employed if our methods were used to study different ranches.

Our model to predict forage harvest by elk has not been validated from energy metabolism studies with elk. We expect the precision of our estimates to be lower than expected from validated models of domestic animal metabolism; yet, better than simple predictions made from an "average elk," or using some average definition of animal unit equivalency. Importantly, our approach accounts for differences among elk populations in sex ratios and age distributions. Compared to domestic animals, there are few scientific studies of energy metabolism in elk. Clearly our ability to model digestion and metabolism of elk would be improved if more studies were completed with elk. Our approach was to use equations specific for elk when available. However, for many equations we assumed that relationships for elk were similar to domestic cattle, scaling the equations for differences in mature size and output rates. Many aspects of energy metabolism are similar among ruminants of different species (e.g., sheep and cattle, ARC 1980). Several previous studies have applied relationships from cattle studies to wild ungulates (e.g., Moen 1973, 1978, 1983, Nelson and Leege 1982, Hudson and White 1985).

Our approach in this study was to allocate all forage to cattle and elk, defining the forage resource as the amount of forage that could be harvested without damaging the range resource. In other words, to manage a range resource responsibly, we assumed that forage harvest must be limited to a certain degree of use - the degree of use currently experienced by each ranch. Hence, under this assumption, forage consumed by elk (accounting for dietary overlap) reduced forage available to cattle. An increase in elk herd size would lead to a reduction in cattle herd size, and conversely an increase in cattle herd size would require a reduction in the number of elk. Hobbs et al. (1996a,1996b) showed that elk grazing led to decreased forage intake, and reduced weight gains for cattle. Some responses demonstrated threshold effects-i.e., if sufficient forage was available to cattle after elk grazing, then cattle showed little response to elk grazing. Our assumptions and the results of Hobbs et al. (1996a,1996b) are both consistent with accepted definitions of competition, i.e., for competition for forage to occur, both cattle and elk must be consuming the same forage species in the same area and the forage species must be in short supply (Vavra 1992).

Simulating ranches as if no elk existed was used as a tool to quantify the economic impact elk had on beef cattle enterprises. We emphasize, however, that it is seldom possible or legal to remove all elk from a ranch (Youmans 1992). In our experience, very few ranchers desire to remove all elk (or other wildlife) from their properties. Further, an increasing number of people outside of agriculture recognize the importance of livestock operations in providing/conserving wildlife habitat. Alternatives for managing elk, i.e., strategies to maintain herd sizes at reasonable levels and (or) recoup income lost or foregone by providing habitat, are vital to the sustainability of many ranches.

\section{Implications}

Our results show that providing elk habitat on private land does represent an economic cost to ranches. Importantly, our results also suggest that Montana ranches represented by our sample can recover most if not all of these costs, and in some cases actually profit from elk by implementing various elk management strategies. Our study focused on expenses associated with forage use. Elk may also be responsible for damage to fences and other facilities. Lacey et al. (1993) reported that annual non-feed expenses associated with wildlife were $\$ 401$ per ranch.

Feed costs generally represent one of the largest expenses for beef cattle producers. Grazed forage is often a more economical feed source than harvested or purchased feed. Our results suggest that the more dependent ranches are on rangeland, and the more efficiently they produce beef (i.e., lower unit cost of production, $\$ / \mathrm{kg}$ ), the more these ranches have to lose from providing elk habitat. More efficient ranches stand to benefit most from exchange of use programs, while ranches that are less efficient should benefit most from direct compensation. The greatest benefits from the Montana Block Management program appear to come from improved hunter management and compensation for access and habitat rather than from reduction in elk numbers.

Our survey of outfitters suggests that leasing of hunting access may be a viable method to recoup costs for some ranches. Commercial recreation values associated with elk provide incentives for ranches to provide elk habitat (Anderson and Hill 1995). Multiple factors determine the market values of recreational leases. However, market incentives may not address needs associated with non-game species or opportunities for low income people (Burger and Teer 1981, Jordan and Workman 1989), nor longer term management objectives related to biodiversity (Freese and Trauger 2000, Gowdy 2000).

The ranches studied illustrate that solutions to wildlife-livestock issues are situation specific. A single, universal recommendation is not likely to be acceptable. We considered only 3 options for recovering costs associated with elk utilizing private ranges. Other options may play important roles in solutions to wildlifelivestock problems (e.g., conservation easements, different types of leases, owner-managed recreational enterprises, etc.) (Knight 1996a,1996b, 1996c). Wildlife-livestock interactions are complex and dynamic. Improved understanding of these systems and cooperative approaches are needed to identify sustainable and equitable solutions (Swensson and Knight 1998). 


\section{Appendix: Description of Elk Forage Consumption Model}

The model is based on a 1-day time step. Metabolizable energy (ME) requirements for maintenance (MEM, Mcal) are predicted from current animal weight (WT) and adjusted for season to reflect energy expenditures for travel (Nelson and Leege 1982, Jiang and Hudson 1993).

$$
M E M=\frac{B M\left(W T^{0.75}\right)}{K M}
$$

where, $\mathrm{BM}=0.1002,0.1094,0.1138,0.1072$ in winter, spring, summer, and fall, respectively. Efficiency of ME use for maintenance (KM), is predicted as a function of diet energy density (ME/kg dry matter [MEDM]) following NRC (1984).

$$
K M=\frac{1.37 M E D M-1.38 M E D M^{2}+0.0105 M E D M^{3}-1.12}{M E D M}
$$

Postweaning growth is simulated based on WT, asymptotic mature weight (AWT), and weight gain (WTG) following data presented by Murie (1951) and equations by Moen (1973) as:

$$
W T G=B 1(A W T-W T)
$$

where $\mathrm{B} 1=0.0030$ for bulls and 0.0035 for cows, and AWT is assumed to be 350 and $260 \mathrm{~kg}$ for bulls and cows, respectively (Nelson and Leege 1982). Predictions of ME requirements for gain (MEG) are based on NRC (1984), and assume that the composition of gains for elk and cattle are similar at similar stages of maturity and similar relative rates of growth. For bulls,

$$
M E G=\frac{0.0493 W T^{0.75}\left(W T G^{1.097}\right) A R A T I O^{0.847}}{K G}
$$

and for cows,

$$
M E G=\frac{0.0686 W T^{0.75}\left(W T G^{1.119}\right) A R A T I O^{0.869}}{K G}
$$

where ARATIO is the ratio of mature weights for cattle and elk (e.g., 525/260 $=2.02$ in this study). See below for derivation. Postweaning rates of growth for elk are expected to be slower and with lower percent fat than for domestic cattle fed concentrate diets. This prediction accounts for such differences. The efficiency of ME use for gain (KG) is computed based on NRC (1984) as:

$$
K G=\frac{1.42 M E D M-0.174 M E D M^{2}+0.0122 M E D M^{3}-1.62}{M E D M}
$$

For pregnant females, ME requirements for gestation (MEU) is measured as uterine energy deposition (UTE) which has a 15\% efficiency rate and is modeled after Ferrell et al. (1976). Gain in uterine development (UTEG) is computed by the equation:

$$
U T E G=\frac{0.06973 e^{D T(0.0323-0.0000275 D T)} 16.0}{40.0}-U T E
$$

where, the ratio $16.0 / 40.0$ accounts for difference in birth weight between elk and cattle, and UTE is the accumulated UTE on the day of gestation (DT). Then,

$$
M E U=\frac{U T E G}{0.15}
$$

For cows nursing a calf, it is necessary to calculate the fraction of the calf's requirements satisfied by milk, and the cow's added energy requirement to produce milk. First, we assume a 50:50 distribution of male and females calves. Second, we assume that the average nursing time is 120 days, and that calf growth is linear over this period for both sexes. During the nursing period calf $\mathrm{ME}$ requirements $(\mathrm{CMEI})$ are:

$$
C M E I=M E M+M E G
$$

The fraction (FRACT) of MEI supplied by milk is assumed to decrease with calf age, and estimated as:

$$
F R A C T=1.0+\frac{16.0+C W T}{W W T-16.0}
$$

where, $\mathrm{CWT}=$ current calf weight, and $\mathrm{WWT}=$ weaning weight (note that birth weight $=16 \mathrm{~kg}$ ). Weaning weights are assumed to be $85.2 \mathrm{~kg}$ for bulls and $79.5 \mathrm{~kg}$ for cows (Nelson and Leege 1982). Then, CMEI supplied by forage is computed as:

$$
C M E I F=C M E I(1.0-F R A C T)
$$

The ME required by the cow to produce the milk consumed by the calf (MEL) is estimated as:

$$
M E L=\frac{C M E I(F R A C T)}{0.85 K M}
$$

where, 0.85 accounts for metabolizability of milk consumed by the calf (NRC 1989).

For all animals past weaning age, total ME consumed (MEI) is:

$$
M E I=M E M+M E G+M E U+M E L
$$

where MEG, MEU, or MEL could be zero, depending on animal age, sex, and physiological state. Metabolizable energy consumed was translated into animal unit months (AUM $=360 \mathrm{~kg}$ dry matter, SRM 1989) as:

$$
A U M=\frac{M E I+C M E I F}{360(M E D M)}
$$

The amount of forage consumed by elk that could have been consumed by cattle is then predicted as:

$$
A D J A U M=A U M(O V E R L A P)
$$

where, OVERLAP is the product of spatial and dietary overlap expressed in decimal form.

For the purposes of this study we assumed that average birth and weaning dates for elk calves were June 1 and September 28, respectively (Skovlin 1982, Taber et al. 1982, Nelson and Leege 1982). To recognize that the number of elk using a ranch was not constant throughout the year, the model was constructed to simulate forage intake by elk during different periods of time specific for each ranch. For each period, inputs to the model included descriptions of the elk population, average forage quality during the period (i.e., MEDM), and OVERLAP.

\section{Derivation of energy cost of gain for elk}

From NRC (1984) the net energy of live weight gain for female cattle is:

$$
N E_{G C}=0.0686 W T C^{0.75}\left(W T G C^{1.119}\right)
$$

where, WTC $=$ current live weight $(\mathrm{kg})$ and WTGC $=$ live weight gain $(\mathrm{kg} / \mathrm{d})$. 
Dividing by WTGC, net energy per kg WTGC is:

$$
N E K G_{G C}=0.0686 W T C^{0.75}\left(W T G C^{0.119}\right)
$$

Our assumption is that the net energy for gain for elk is similar to that of cattle when gains and weights are at similar stages of maturity (i.e., fraction of mature size). Hence, if the current weight (WTE) and gain (WTGE) for elk are proportional to the ratio of mature weights for elk (AWTE) and cattle (AWTC), then:

$$
\begin{gathered}
W T E=W T C\left(\frac{A W T E}{A W T C}\right) \\
W T G E=W T G C\left(\frac{A W T E}{A W T C}\right)
\end{gathered}
$$

Finally, solve for an adjustment factor $(\mathrm{Z})$ that equalizes the net energy for gain for cattle and elk when gains are at similar fractions of mature weight.

$$
\begin{gathered}
0.0686 W_{T C}^{0.75}\left(W T G C^{0.119}\right)=0.0686\left(W T C \frac{A W T E}{A W T C}\right)^{0.75}\left(W T G C \frac{A W T E}{A W T C}\right)^{0.119}(Z) \\
Z=\left(\frac{A W T C}{A W T E}\right)^{0.869}
\end{gathered}
$$

Note, that the coefficient $0.869=0.75+1.119-1.0$. Similarly, the coefficient for male elk is $0.847=0.75+1.097-1.0$.

\section{Literature Cited}

Adams, A. W. 1982. Migration, p. 301-321. In: J. W. Thomas and D. E. Toweill (eds.), Elk of North America: ecology and management. Stackpole Books, Harrisberg, Penn.

AIt, K. L., M. R. Frisina, and F. J. King. 1992. Coordinated management of elk and cattle, a perspective-Wall Creek Wildl. Manage. Area. Rangelands 14:12-15.

Anderson, T. L. and P. J. Hill. 1995. From a liability to an asset: developing markets for wildlife, p. $x i-x v$. In: T. L. Anderson and P. J. Hill (eds.), Wildlife in the Marketplace. Rowman and Littlefield Publishers, Inc, Lanham, Md.

Anderson, E. W. and R. J. Scherzinger. 1975. Improving quality of winter forage for elk by cattle grazing. J. Range Manage. 28:120-125.

ARC. 1980. The nutrient requirements of ruminant livestock. Commonwealth Agr. Bureaux, Farnham Royal, U.K.

Arychuk, C. E. 2000. Setting stocking rates for pastures. The Tracker 4:72-73.

Begon, M., J. L. Harper, and C. R. Townsend. 1990. Ecology, individuals, populations and communities. Blackwell Sci. Publ., Inc. Cambridge, Mass.

Burger, G. V. and J. G. Teer. 1981. Economic and socioeconomic issues influencing wildlife management on private land, p. 252-263. In: R. T. Dumke, G. V. Burger, and J. R. March (eds.), Wildlife Management on Private Lands. Wisconsin Wildl. Soc., Madison, Wis.

Cooperrider, A. Y. and J. A. Bailey. 1984. A simulation approach to forage allocation, p. 525-560. In: Developing Strategies for Rangeland Management. Westview Press, Boulder, Colo.

Edge, W. D. and C. L. Marcum. 1990. Elk and cattle on public lands: a new look at an old conflict. West. Wildl. 16(2):12-15.

Ferrell, C. L., W. N. Garrett, N. Hinman. 1976. Growth, development and composition of the udder and gravid uterus of beef heifers during pregnancy. J. Anim. Sci. 42:1477-1489.

Freese, C. H. and D. L. Trauger. 2000. Wildlife markets and biodiversity conservation in North America. Wildl. Soc. Bull. 28:42-51.

Frisina, M. R. and G. Morin. 1991. Grazing private and public land to improve Fleecer elk winter range. Rangelands 13:291-294.

Fuller, W. L. 1997. Elk management strategies for sustainable beef cattle enterprises. M. S. Thesis, Montana State Univ.-Bozeman, Bozeman, Mont.

Gordon, F. A. 1968. Range relationships of elk and cattle on elk winter range, Crow Creek, Montana. Master's Thesis, Montana State Univ., Bozeman, Mont.

Gowdy, J. M. 2000. Terms and concepts in ecological economics. Wildl. Soc. Bull. 28:26-33.

Hart, R. H., K. W. Hepworth, M. A. Smith, and J. W. Waggoner, Jr. 1991. Cattle grazing behavior on a foothill elk winter range in southeastern Wyoming. J. Range Manage. 44:262-266.

Henderson, R. E. and A. O'Herren. 1992. Winter ranges for elk and deer: victims of uncontrolled subdivisions? Western Wildl. 18(2):20-25.

Hobbs, N. T., D. L. Baker, G. D. Bear, and D. C. Bowden. 1996a. Ungulate grazing in sagebrush grassland: Mechanisms of resource competition. Ecol. Appl. 6:200-217.

Hobbs, N. T., D. L. Baker, G. D. Bear, and D. C. Bowden. 1996b. Ungulate grazing in sagebrush grassland: Effects of resource competition on secondary production. Ecol. Appl. 6:218-227.

Holechek, J. L. 1980. Concepts concerning forage allocation to livestock and big game. Rangelands 2:158-159.

Hudson, R. J. and R. G. White. 1985. Computer simulation of energy budgets. p. 261-290. In: R. J. Hudson and R. G. White (eds.) Bioenergetics of wild herbivores. CRC Press, Boca Raton, Fla.

Jiang, Z. and R. J. Hudson. 1993. Seasonal energy requirements of wapiti (Cervus elaphus) for maintenance and growth. Can. J. Anim. Sci. 74:97-102.

Jordan, L. A. and J. P. Workman. 1989. Economics and management of fee hunting for deer and elk in Utah. Wildl. Soc. Bull. 17:482-487.

Kasworm, W. F., L. R. Irby, and H. B. Ihsle Pac. 1984. Diets on ungulates using winter ranges in northcentral Montana. J. Range Manage. 37:67-71.

Kingery, J. L., J. C. Mosley, and K. C. Bordwell. 1996. Dietary overlap among cattle and cervids in northern Idaho forests. J. Range. Manage. 49:8-15.

Knight, J. E. 1996a. Minimizing controversy in wildlife and livestock grazing management. Trans. $61^{\text {st }}$ No. Amer. Wildl. and Natur. Resour. Conf. 137-141.

Knight, J. E. 1996b. Noncontroversial techniques to manage rangeland resources, p 107-111 In: Sharing Common Ground on Western Rangelands. U.S.D.A. For. Ser. Intermountain Research Section. Gen. Tech. Rep. 1NT-GTR-343.

Knight, J. E. 1996c. Conservation easements on Montana ranches. MontGuide 9618 AG.

Knight, J. E., J. M. Fowler, and C. M. Morgan. 1995. Expenses and income associated with fee hunting enterprises. RITF Report No. 41.

Lacey, J. R., K. Jamtgaard, L. Riggle, and T. Hayes. 1993. Impacts of big game on private land in south-western Montana: Landowner perceptions. J. Range Manage. 46:31-37.

Lacey, J. R., S. B. Laursen, J. C. Gilhrist, R. M. Brownson, J. Anzick, and S. Doggett. 1988. Economic and social implications of managing wildlife on private land in Montana. Northwest Sci. 62:1-9.

LaFrance, J. T. and M. J. Watts. 1995. Public grazing in the West and "Rangeland Reform '94". Amer. J. Agr. Econ. 77:447-461.

Loomis, J., D. Donnelly, and C. Sorg-Swanson. 1989. Comparing the economic value of forage on public lands for wildlife and livestock. J. Range Manage. 42:134-138.

Mackie, J. R. 1970. Range ecology and relations of mule deer, elk, and cattle in the Missouri River Breaks, Montana. Wildl. Monogr. 20.

Mereszczak, I. M., W. C. Krueger, and M. Vavra. 1981. Effects of range improvement on Roosevelt elk winter nutrition. J. Range Manag. 34:184-187.

Moen, A. 1973. Wildlife ecology, an analytical approach. W. H. Freeman, San Francisco, Calif.

Moen, A. N. 1978. Seasonal changes in heart rates, activity, metabolism, and forage intake of white-tailed deer. J. Wildl. Manage. 42:715-738.

Moen, A. N., 1983. Agriculture and Wildlife Management. CornerBrook Press, Lansing, N.Y. 
Montana Session Laws. 1995. House Bill 195, p 2216-2225. In: Laws and Resolutions of the State of Montana, Fifty-fourth Legislature. Montana Legislative Services, Helena, Mont.

Murie, O. J. 1951. The Elk of North America. The Stackpole Company, Harrisburg, Penn.

NASS. 2001. Agricultural Prices (PAPBB).National Agricultural Statistics Service, Agricultural Statistics Board, U.S. Department of Agriculture.

http://usda.mannlib.cornell.edu/ - accessed 4/27/01.

Nelson, J. R. 1982. Relationships of elk and other large herbivores, p 415-442. In: J. W. Thomas and D. E. Toweill (eds), Elk of North America: Ecology and Management. Stackpole Books, Harrisburg, Penn.

Nelson, J. R. and T. A. Leege. 1982. Nutritional requirements and food habits, $p$ 323-367. In: J.W. Thomas and D.E. Toweill (eds.), Elk of North America: Ecology and Management. Stackpole Books, Harrisburg, Penn.

NRC. 1984. Nutrient requirements of beef cattle (6th Ed.). National Academy Press, Washington, DC.

NRC. 1989. Nutrient requirements of dairy cattle (6th Ed.). National Academy Press, Washington, DC.

Peek, J. M. 1982. Elk, p 851-861. In: Joseph A. Chapman and George A. Feldhamer (eds), Wild Mammals of North America, Biology, Management, and Economics. John Hopkins Universtiy Press, Baltimore, Md.

SAS. 1992. SAS user's guide: statistics. SAS Inst., Inc., Cary, N.C.

Severson, K. E. and P. J. Urness. 1994. Livestock grazing: A tool to improve wildlife habitat p. 232-249. In: M. Vavra, W. A. Laycock, and R. D. Pieper (eds.), Ecological Implications of Livestock Herbivory in the West. Soc. for Range Manage., Denver, Colo.
Sheehy, D. P. and M. Vavra. 1996. Ungulate foraging areas on seasonal rangeland in northeastern Oregon. J Range Manage. 49:16-23.

Skovlin, J. M. 1982. Habitat requirements and evaluations, p 369-413. In: J. W. Thomas and D. E. Toweill (eds.), Elk of North America: ecology and management. Stackpole Books, Harrisburg, Penn.

Skovlin , J. M., P. J. Edgerton, and R. W. Harris. 1968. The influence of cattle management on deer and elk. Trans. N. A. Wildl. Natur. Resour. Conf. 33:169-178.

Smith, D. R. 1961. Competition between cattle and game on elk winter range. Univ. of Wyoming Agr. Exp. Sta.

Society for Range Management. 1989. A glossary of terms used in range management. Denver, Colo.

Stevens, D. R. 1966. Range relationships of elk and livestock, Crow Creek Drainage, Montana. J. Wildl. Manage. 30:349-363.

Stoddart, L. A. and A. D. Smith. 1955. Range management. McGraw-Hill, N.Y.

Swensson, E. J. and J. E. Knight. 1998 Identifying Montana hunter/rancher problems and solutions. J. Range Manage. 51:423--428

Swensson, E. J. and J. E. Knight. 2001. Hunter management strategies used by Montana ranchers. Wildl. Soc. Bull. 29:306-310.

Taber, R.D, K. Raedeke, and D. A. McCaughran. 1982. Population Characteristics, p 279-298. In: J. W. Thomas and D. E. Toweill (eds.), Elk of North America: ecology and management. Stackpole Books, Harrisburg, Penn.

Tefler, E. S. and G. W. Scotter. 1975. Potential for game farming in boreal aspen forests of western Canada. J. Range Manage. 28:172-181.

Tess, M. W. and B. W. Kolstad. 2000a. Simulation of cow-calf production systems in a range environment. I. Model development. J. Anim. Sci. 78:1159-1169.
Tess, M. W. and B. W. Kolstad. 2000b. Simulation of cow-calf production systems in a range environment. II. Model evaluation. J. Anim. Sci. 78:1170-1179.

Torell, L. A. and J. M. Fowler. 1992. Grazing fees: how much is fair? Agr. Exp. Sta. Rept. 666. New Mexico State Univ., Las Cruces, N.M.

Vallentine, J. F. 1990. Grazing management. Academic Press, Inc., San Diego, Calif.

Vavra, M. 1992. Livestock and big game forage relationships. Rangelands 14:57-59.

Vavra, M, M. McInnis, and D. Sheehy. 1989. Implications of dietary overlap to management of free-ranging large herbivores. Proc. West. Sect. ASAS. 40:489-495.

Wagner, F. H. 1969. Ecosystem concepts in fish and game management. p. 259-307. In: G. M. Van Dyne (Ed.). The ecosystem concept in natural resource management. Academic Press, New York, N.Y.

Wambolt, C. L., M. R. Frisina, K. S. Douglass, and H. W. Sherwood. 1997. Grazing effects on nutritional quality of bluebunch wheatgrass for elk. J. Range Manage. 50:503-506.

Wisdom, M. 1992. The Starkey Project: new technologies chase old questions about deer and elk management. Western Wildl. 18:32-38

Witmer, G. W. and D. S. deCalesta. 1983. Habitat use by female Roosevelt elk in the Oregon coast range. J. Wildl. Manage. 47:933-939.

Yeo, J. J., J. M. Peek, W. T. Wittenger, and C. T. Kvale. 1993. Influence of rest-rotation cattle grazing on mule deer and elk habitat use in east-central Idaho. J. Range Mange. $46: 245-250$.

Youmans, H. B. 1992. Editor: Elk Management Plan. Montana Dept. of Fish, Wildl., and Parks, Helena, Mont. 